\title{
ACACIA MANGIUM, HOPEA ODORATA AND KHAYA IVORENSIS GROWN IN EX-MINING AND BRIS PLANTATION PLOTS: RESISTANGE AGAINST SUBTERRANEAN TERMITES
}

\author{
Roszaini $\mathrm{K}^{1,}$ *, Wan-Rashidah AK, Mohamad-Fakri I \& Ang LH \\ Forest Research Institute Malaysia, 52109 Kepong, Selangor, Malaysia \\ *roszaini@frim.gov.my
}

Submitted November 2018; accepted April 2019

\begin{abstract}
This study aimed to evaluate the natural durability of wood from ex-mining and BRIS plantation plots of three timber species, namely, Acacia mangium, Hopea odorata and Khaya ivorensis against subterranean termites. The assessment involved two tests—accelerated laboratory test (4 weeks) and field test (16 weeks) —where samples were exposed to the termite Coptotermes curvignathus, after which weight loss and visual rating were evaluated. The main findings showed that the timber grown in ex-mining areas had higher resistance against subterranean termites compared with timber from BRIS area.
\end{abstract}

Keywords: Fast-grown trees, soil types, heavy metal, durability, Coptotermes curvignathus

\section{INTRODUCTION}

Fast-growing and high-yielding forest plantations are becoming an important source of wood in the tropics due to lack of supplies from the forest stands. Besides survival and growth, large plantation programmes should also consider the quality and utilisation potential of tree species for the production of short-term, large-diameter timber while having the same high durability of trees from forest stands aged 40 to 50 years old (Laurila 1995).

Malaysia has large stretches of idle and degraded lands which can be recovered for plantation forestry. There are about 200,000 ha of BRIS (Beach Ridges Interspersed with Swales) soils in the east coast of Peninsular Malaysia and Sabah and more than 100,000 ha of ex-mining areas mainly in the states of Johore, Perak and Selangor (Hashim et al. 2015). Ex-mining land structures are not stable as the sand is mixed with pebbles, single grain and has high level of soil drainage. The soil has high contents of heavy metals that are likely to affect the growth of trees and has low rates of fertility, water holding capacity and nutrient fertilisers but high in permeability with high surface temperature (Wan Asma et al. 2011). BRIS or sandy soils originate from sediment or sand from the sea that accumulated from erosion of layers of steep cliffs by the sea during monsoon seasons
(Nossin 1964). It has high sandy texture (> $90 \%$ ), low fertility, low cation exchange capacity and low water holding capacity (Mohd Khairi et al. 2011). Therefore, remodelling these sites by replanting forest trees is very challenging. However, recovered mining area can produce the same or more productive forest than natural forest (Burger \& Zipper 2002).

Acacia mangium, Hopea odorata and Khaya ivorensis, high-value and moderately durable hardwood, were among the first few species introduced as planting materials meant for wood industries. They were selected due to their high growth rates (Lok \& Ong 2002). The cultivation of these fast-growing species is one of the measures to overcome the shortage of timber supplies from natural forest.

Soil types affect the durability of timber because different types of soil may breed different types of microorganisms (Berg \& Smalla 2009). Hence, precise knowledge of the natural durability of wood in relation to different soils would benefit the wood utilisation and wood preservation industries. Therefore, the study of wood resistance from ex-mining and BRIS soil should be assessed to determine the optimum harvest age and whether the content of heavy metal affects the natural durability of the wood. Several variables such as climate, atmospheric 
droplets, heavy metal concentration in the soil, soil properties and plant maturity at harvest levels (the height at which the tree is cut down) influence the absorption of heavy metal into the trees (Ncube \& Phiri 2015).

Our hypothesis was that heavy metal contributed to the natural durability of trees against termites. Thus, the present study was designed to evaluate the natural termite resistance of juvenile trees, i.e. $<20$ years old. We used 14- to 16-year-old A. mangium, $H$. odorata and $K$. ivorensis wood grown in exmining and BRIS areas. The evaluation was based on accelerated laboratory and field tests against subterranean termites.

\section{MATERIALS AND METHODS}

Three plantation timber species, A. mangium, $H$. odorata and K. ivorensis, ages between 14 and 16 years old were extracted from two sites, namely, (1) ex-mining area at the Forest Research Institute Malaysia (FRIM) Research Station, Bidor, Perak and (2) BRIS area at FRIM Research Station, Setiu, Terengganu. The same timber species with similar ages from a plantation established on mineral soil at Bukit Hari, FRIM were used as control.

\section{Soil metal uptake studies}

Soil samples were taken randomly at each site at fixed depths, i.e. $0-5,5-15,15-30$ and $30-45 \mathrm{~cm}$ using hand auger $(2.5 \mathrm{~cm}$ diameter). Soil samples were dried in an air-circulating oven at $25^{\circ} \mathrm{C}$ and passed through a 10 -mesh sieve $(<2 \mathrm{~mm})$. After quartering, the samples were ground to 80 meshes $(<180 \mu \mathrm{m})$ using mortar. Samples were digested in 4:1 ratio of concentrated nitric:perchloric acids until all brown fumes disappeared, then evaporated to near dryness. The residue was then diluted with $20 \mathrm{~mL} 2 \% \mathrm{HNO}_{3}$ and boiled further to release any fumes, cooled and filtered through Whatman No. 42 filter paper into $50 \mathrm{~mL}$ volumetric flask and marked up to the volume with distilled water. The solution was analysed for arsenic (As), cadmium (Cd), mercury ( $\mathrm{Hg}$ ), plumbum $(\mathrm{Pb})$ and chromium ( $\mathrm{Cr}$ ) using inductively coupled plasma atomic emission spectrometry (Thompson \& Wood 1982). Soil $\mathrm{pH}$ was measured using 2.5:1 deionised water: soil sample. Loss on ignition and cation exchange capacity were measured following Ball (1964) and Smith and Atkinson (1975).

\section{Termite bioassay}

\section{No-choice test}

Heartwood specimens of $25 \mathrm{~mm}$ length $\times 25 \mathrm{~mm}$ width $\times 6 \mathrm{~mm}$ height were cut from the butt end of each timber species. The samples were dried to $12 \%$ moisture content in a kiln dryer and their weights recorded. Samples were then subjected to termite laboratory bioassay based on the AWPA E1-17 no-choice test procedure (AWPA 2017) with some modifications. The tests were conducted in five replicates.

Subterranean termite Coptotermes curvignathus was collected from active field colonies within the FRIM campus using trapping technique (Kirton et al. 1998). Screw-top bottles, 80-mm in diameter $\times 130 \mathrm{~mm}$ in height were filled with $200 \mathrm{~g}$ of sterilised sand and $30 \mathrm{~mL}$ distilled water. Five bottles for each timber species from the regular plantation were used as control. The bottles were left overnight to equilibrate to laboratory condition. A block of the specimen was placed at the bottom of each bottle. A total of 400 termites (360 workers and 40 soldiers) were added into the bottles. All bottles were stored in an incubator maintained at $22 \pm 2{ }^{\circ} \mathrm{C}$ and $65 \pm 5 \%$ relative humidity for 28 days. During this period, the number of days for $100 \%$ mortality was recorded. At the end of the fourth week, specimen blocks were removed, cleaned by brushing off adhering soil and carton debris, oven dried overnight and reweighed. For every bottle, the remaining live termites were weighed and recorded. The specimen blocks were rated visually on a scale of 0 to 10 where 10 was sound and 0 was total failure (Table 1 ).

\section{Aboveground test}

Heartwood sample $(100 \mathrm{~mm}$ length $\times 40 \mathrm{~mm}$ width $\times 20 \mathrm{~mm}$ height) was cut from the butt end of three trees of each timber species and dried to $12 \%$ moisture content. The aboveground test was carried out in FRIM campus with a relative temperature between 22 and $28{ }^{\circ} \mathrm{C}$ to observe higher termite activity during the 16 weeks of the exposure period based on AWPA E21-06 (AWPA 2012) with some modifications. Twelve drums containing samples for each tree were installed at the area where at least one subterranean termite species existed (Figure 1). A layer of Hevea brasiliensis (rubberwood), a highly susceptible timber substrate, was placed at the bottom of 
Table 1 Visual rating system based on AWPA (2017)

\begin{tabular}{cl}
\hline Rating & Description \\
\hline 10 & Sound \\
9.5 & Trace, surface nibbles permitted \\
9 & Slight attack up to $3 \%$ of cross sectional area affected \\
8 & Moderate attack, $3-10 \%$ of cross sectional area affected \\
7 & Moderate/severe attack, penetration, $10-35 \%$ of cross sectional area affected \\
6 & Severe attack, $30-50 \%$ of cross sectional area affected \\
4 & Very severe attack, $50-75 \%$ of cross sectional area affected \\
0 & Failure \\
\hline
\end{tabular}

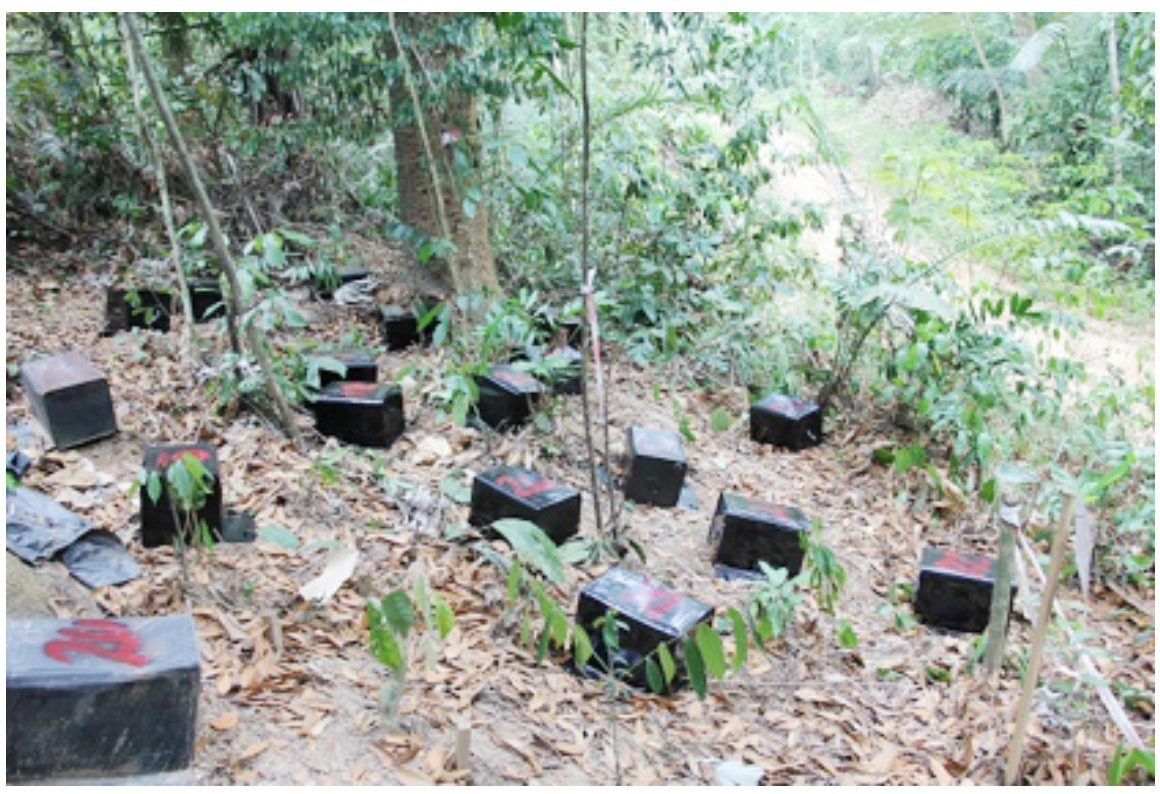

Figure 1 Aboveground test at FRIM campus

the drum. One square section of galvanised welded mesh sheet (25-mm square opening) was placed on top of the timber substrate. Test specimens sandwiched with $H$. brasiliensis were placed on top of the galvanised welded mesh. The test specimens were randomly arranged to avoid contact with each other. All samples were left undisturbed for 16 weeks. Samples were then removed, cleaned by brushing off adhering soil and carton debris and oven dried overnight. Sample weight and weight loss were recorded. The condition of the test samples was rated visually based on AWPA (2012) (Table 2). The test was conducted in 10 replicates giving a total of 120 woodblock experiments.

\section{Statistical analysis}

All data on weight loss, degree of attack and termite mortality rates were analysed using
Minitab version 15 through one way analysis of variance (ANOVA) followed by least significance difference test at $\mathrm{p}<0.05$ for comparison.

\section{RESULTS AND DISCUSSION}

\section{Concentrations of heavy metals in soil}

The range and mean concentrations of As, Cd, $\mathrm{Hg}, \mathrm{Pb}$ and $\mathrm{Cr}$ in soil sampled in the plantation are summarised in Table 3. In all plantations, As concentrations in the soil from Setiu at all depths were slightly lower (2.06-2.79 $\mathrm{mg} \mathrm{kg}^{-1}$ ) than Bidor $\left(2.50-5.79 \mathrm{mg} \mathrm{kg}^{-1}\right)$. Arsenic concentrations at all sites were below the local environmental standard of $<50 \mathrm{mg} \mathrm{kg}^{-1}$ (EQA 1974). For wood, low As content will lead to lack of resistance against pesticide as it is the main insecticidal component in providing protection from wood-attacking insects including termites and marine borers. It 
Table 2 Visual rating system based on AWPA (2012)

\begin{tabular}{cl}
\hline Rating & Description \\
\hline 10 & Sound surface nibbles permitted \\
9 & Light attack \\
7 & Moderate attack and penetration \\
4 & Heavy \\
0 & Failure \\
\hline
\end{tabular}

Table 3 Concentrations of heavy metals in surface soil of plantations

\begin{tabular}{|c|c|c|c|c|c|c|}
\hline \multirow[t]{2}{*}{ Timber species } & \multirow[t]{2}{*}{ Heavy metal $\left(\mathrm{mg} \mathrm{kg}^{-1}\right)$} & \multirow[t]{2}{*}{ Depth $(\mathrm{cm})$} & \multicolumn{3}{|c|}{ Site } & \multirow[t]{2}{*}{ EQA (1974) } \\
\hline & & & Bidor & Setiu & Bukit Hari & \\
\hline \multirow[t]{16}{*}{ Acacia mangium } & \multirow[t]{4}{*}{ As } & $0-5$ & $2.60^{c}$ & $2.06^{\mathrm{b}}$ & $27.56^{\mathrm{a}}$ & \multirow[t]{4}{*}{50} \\
\hline & & $5-15$ & $5.36^{\mathrm{a}}$ & $2.09^{b}$ & $30.53^{\mathrm{a}}$ & \\
\hline & & $15-30$ & $4.48^{\mathrm{b}}$ & $2.64^{\mathrm{a}}$ & $25.14^{\mathrm{ab}}$ & \\
\hline & & $30-45$ & $4.67^{\mathrm{b}}$ & $2.72^{\mathrm{a}}$ & $22.98^{\mathrm{b}}$ & \\
\hline & \multirow[t]{4}{*}{$\mathrm{Cd}$} & $0-5$ & n.d. & $0.04^{\mathrm{b}}$ & n.d. & \multirow[t]{4}{*}{ NA } \\
\hline & & $5-15$ & n.d. & $0.15^{\mathrm{a}}$ & n.d. & \\
\hline & & $15-30$ & n.d. & $0.10^{\mathrm{a}}$ & n.d. & \\
\hline & & $30-45$ & n.d. & $0^{\mathrm{b}}$ & n.d. & \\
\hline & \multirow[t]{4}{*}{$\mathrm{Hg}$} & $0-5$ & n.d. & 0.75 & n.d. & \multirow[t]{4}{*}{ NA } \\
\hline & & $5-15$ & n.d. & n.d. & n.d. & \\
\hline & & $15-30$ & n.d. & n.d. & n.d. & \\
\hline & & $30-45$ & n.d. & n.d. & n.d. & \\
\hline & \multirow[t]{4}{*}{$\mathrm{Pb}$} & $0-5$ & $36.36^{\mathrm{c}}$ & $7.15^{\mathrm{a}}$ & $26.25^{\mathrm{a}}$ & \multirow[t]{4}{*}{100} \\
\hline & & $5-15$ & $48.99^{\mathrm{b}}$ & $4.19^{\mathrm{b}}$ & $26.34^{\mathrm{a}}$ & \\
\hline & & $15-30$ & $51.74^{\mathrm{ab}}$ & $5.18^{\mathrm{b}}$ & $27.74^{\mathrm{a}}$ & \\
\hline & & $30-45$ & $55.97^{\mathrm{a}}$ & $0.70^{\mathrm{c}}$ & $25.29^{\mathrm{a}}$ & \\
\hline \multirow[t]{16}{*}{ Hopea odorata } & \multirow[t]{4}{*}{ As } & $0-5$ & $2.83^{c}$ & $1.34^{\mathrm{b}}$ & $2.43^{\mathrm{b}}$ & \multirow[t]{4}{*}{50} \\
\hline & & $5-15$ & $2.50^{c}$ & $1.74^{\mathrm{b}}$ & $2.10^{\mathrm{b}}$ & \\
\hline & & $15-30$ & $3.29^{b}$ & $2.79 \mathrm{a}$ & $2.79^{b}$ & \\
\hline & & $30-45$ & $4.70^{\mathrm{a}}$ & $1.44^{\mathrm{b}}$ & $4.10^{\mathrm{a}}$ & \\
\hline & \multirow[t]{4}{*}{$\mathrm{Cd}$} & $0-5$ & n.d. & $0.06^{\mathrm{a}}$ & n.d. & \multirow[t]{4}{*}{ NA } \\
\hline & & $5-15$ & n.d. & $0.08^{\mathrm{a}}$ & n.d. & \\
\hline & & $15-30$ & n.d. & $0.09^{\mathrm{a}}$ & n.d. & \\
\hline & & $30-45$ & n.d. & $0.06^{\mathrm{a}}$ & n.d. & \\
\hline & \multirow[t]{4}{*}{$\mathrm{Hg}$} & $0-5$ & n.d. & n.d. & n.d. & \multirow[t]{4}{*}{ NA } \\
\hline & & $5-15$ & n.d. & n.d. & n.d. & \\
\hline & & $15-30$ & n.d. & n.d. & n.d. & \\
\hline & & $30-45$ & n.d. & n.d. & n.d. & \\
\hline & $\mathrm{Pb}$ & $0-5$ & $39.02^{c}$ & $0.51^{\mathrm{c}}$ & $35.01^{\mathrm{b}}$ & 100 \\
\hline & & $5-15$ & $44.08^{\mathrm{b}}$ & $1.53^{\mathrm{a}}$ & $37.08^{\mathrm{b}}$ & \\
\hline & & $15-30$ & $48.02^{\mathrm{a}}$ & $0.93^{\mathrm{bc}}$ & $40.22^{\mathrm{a}}$ & \\
\hline & & $30-45$ & $49.55^{\mathrm{a}}$ & $0.93^{\mathrm{bc}}$ & $41.25^{\mathrm{a}}$ & \\
\hline Khaya ivorensis & As & $0-5$ & $3.13^{c}$ & $2.08^{\mathrm{a}}$ & $2.53^{c}$ & 50 \\
\hline & & $5-15$ & $2.87^{c}$ & $2.60^{\mathrm{a}}$ & $2.87^{\mathrm{c}}$ & \\
\hline & & $15-30$ & $4.27^{\mathrm{b}}$ & $2.43^{\mathrm{a}}$ & $3.28^{\mathrm{b}}$ & \\
\hline & & $30-45$ & $5.79^{\mathrm{a}}$ & $2.06^{\mathrm{a}}$ & $4.33^{\mathrm{a}}$ & \\
\hline & $\mathrm{Cd}$ & $0-5$ & n.d. & $1.59^{\mathrm{b}}$ & n.d. & NA \\
\hline & & $5-15$ & n.d. & $3.15^{\mathrm{a}}$ & n.d. & \\
\hline & & $15-30$ & n.d. & $0.01^{\mathrm{c}}$ & n.d. & \\
\hline & & $30-45$ & n.d. & $0.07^{c}$ & n.d. & \\
\hline & $\mathrm{Hg}$ & $0-5$ & n.d. & n.d. & n.d. & NA \\
\hline & & $5-15$ & n.d. & n.d. & n.d. & \\
\hline & & $15-30$ & n.d. & n.d. & n.d. & \\
\hline & & $30-45$ & n.d. & n.d. & n.d. & \\
\hline & $\mathrm{Pb}$ & $0-5$ & $38.86^{c}$ & $4.00^{\mathrm{a}}$ & $39.96^{\mathrm{b}}$ & 100 \\
\hline & & $5-15$ & $44.44^{\mathrm{b}}$ & $1.22^{\mathrm{b}}$ & $40.14^{\mathrm{b}}$ & \\
\hline & & $15-30$ & $49.65^{\mathrm{a}}$ & $1.05^{\mathrm{b}}$ & $42.65^{\mathrm{ab}}$ & \\
\hline & & $30-45$ & $47.00^{\mathrm{a}}$ & $1.10^{\mathrm{b}}$ & $44.37^{\mathrm{a}}$ & \\
\hline
\end{tabular}

n.d. = not detected; NA = not available; values with the same letter within the same column are not significantly different $(\mathrm{p}<0.05)$; EQA is the local environment standard 
also improves the weather resistance of treated timber and may assist paint adherence in the long term. Cadmium was only detected in the Setiu plantations (0 to $3.15 \mathrm{mg} \mathrm{kg}^{-1}$ ) and not in Bidor and Bukit Hari. Mercury was only detected in the $0-5 \mathrm{~cm}$ depth $\left(0.75 \mathrm{mg} \mathrm{kg}^{-1}\right)$ soil around A. mangium trees in Setiu. Plumbum content in the soil in Bidor (36.36-55.97 $\mathrm{mg} \mathrm{kg}^{-1}$ ) was greater than that in Setiu $\left(0.51-7.15 \mathrm{mg} \mathrm{kg}^{-1}\right)$.

\section{Concentrations of heavy metals in stems}

Concentrations of $\mathrm{As}, \mathrm{Cd}, \mathrm{Hg}, \mathrm{Pb}$ and $\mathrm{Cr}$ in the stems of the three plantation species are summarised in Table 4. Results showed that the occurrence of the five heavy metals varied according to species and sites. Concentration of As in A. mangium stem was higher in Bukit Hari (1.40 $\left.\mathrm{mg} \mathrm{kg}^{-1}\right)$ than in Bidor $\left(1.19 \mathrm{mg} \mathrm{kg}^{-1}\right)$ and Setiu $\left(0.86 \mathrm{mg} \mathrm{kg}^{-1}\right)$ samples. Acacia mangium planted in Bukit Hari also had the highest $\mathrm{Cd}\left(0.28 \mathrm{mg} \mathrm{kg}^{-1}\right)$ content than the other two plantations, i.e. Bidor $\left(0.11 \mathrm{mg} \mathrm{kg}^{-1}\right)$ and Setiu (0.01 $\mathrm{mg} \mathrm{kg}^{-1}$ ) but its $\mathrm{Hg}, \mathrm{Pb}$ and Cr contents were the second highest. Samples from Setiu had the lowest contents of $\mathrm{Cd}, \mathrm{Hg}, \mathrm{Pb}$ and Cr. This showed that A. mangium had good phytoremediation compared with the other two species (Jeyanny et al. 2017).

Highest As (1.61 mg kg-1), Pb (9.90 $\left.\mathrm{mg} \mathrm{kg}^{-1}\right)$ and Cr $\left(0.51 \mathrm{mg} \mathrm{kg}^{-1}\right)$ concentrations in H. odorata stem were observed in Bukit Hari samples and Setiu (only for $\mathrm{Cr}$ ) while the highest uptake of $\mathrm{Cd}\left(0.51 \mathrm{mg} \mathrm{kg}^{-1}\right)$ and $\mathrm{Hg}\left(0.13 \mathrm{mg} \mathrm{kg}{ }^{-1}\right)$ were in the sample from Bidor (Table 4). Meanwhile, the lowest contents of As $\left(1.61 \mathrm{mg} \mathrm{kg}^{-1}\right)$ and $\mathrm{Cr}$ $\left(0.40 \mathrm{mg} \mathrm{kg}^{-1}\right)$ were observed in Bidor samples. For $K$. ivorensis, Bukit Hari samples had the highest contents of $\mathrm{Pb}\left(2.63 \mathrm{mg} \mathrm{kg}^{-1}\right)$ and $\mathrm{Cr}$ $\left(0.93 \mathrm{mg} \mathrm{kg}^{-1}\right)$, and had the second highest contents of As, Cd and Hg. Bidor samples had the highest uptake of As $\left(1.38 \mathrm{mg} \mathrm{kg}^{-1}\right)$ and $\mathrm{Hg}\left(0.12 \mathrm{mg} \mathrm{kg}^{-1}\right)$, but they had higher $\mathrm{Pb}$ (1.61 $\left.\mathrm{mg} \mathrm{kg}^{-1}\right)$ and $\mathrm{Cr}\left(0.54 \mathrm{mg} \mathrm{kg}^{-1}\right)$ contents compared with Setiu samples $\left(0.35 \mathrm{mg} \mathrm{kg}^{-1}\right.$ and $0.39 \mathrm{mg} \mathrm{kg}^{-1}$ respectively). Overall, the uptake order of heavy metals in the stem of $K$. ivorensis was $\mathrm{As}>\mathrm{Pb}>\mathrm{Cr}>\mathrm{Hg}>\mathrm{Cd}$.

The uptake of all heavy metals (As, $\mathrm{Pb}, \mathrm{Hg}$ and $\mathrm{Cr}$ ) by the three timber species planted at three different sites was far below the reported value for various sawdust particles collected from 15 sawmills in Sapele, Nigeria (32-84 $\mathrm{mg} \mathrm{kg}^{-1}$, $40-250 \mathrm{mg} \mathrm{kg}^{-1}, 0.50-40 \mathrm{mg} \mathrm{kg}^{-1}$ and $1.46-$ $160.50 \mathrm{mg} \mathrm{kg}^{-1}$ respectively) (Nwajei \& Iwegbue 2007). Only Cd content was within the range reported ( 0 to $0.5 \mathrm{mg} \mathrm{kg}^{-1}$ ). The difference in uptake values is related to the characteristics of the tree. Plants vary in their ability to absorb and accumulate minerals from the soil solution (Aldoobie \& Beltagi 2013).

\section{No-choice test}

The average weight loss by termites, termite survival and visual rating are given in Figures 2 and 3, and Table 5 respectively. Lower weight loss in A. mangium from Bidor $(1.23 \%), H$. odorata from Setiu (1.35\%) and K. ivorensis from Bukit Hari $(1.26 \%)$ compared with the same species

Table 4 Average heavy metal content in stem of the plantation trees at three different sites

\begin{tabular}{llccccc}
\hline Timber species & Site & \multicolumn{5}{c}{ Heavy metal $\left(\mathrm{mg} \mathrm{kg}^{-1}\right)$} \\
\cline { 2 - 6 } & & As & Cd & Hg & Pb & $\mathrm{Cr}$ \\
\hline A. mangium & Bukit Hari & $1.40^{\mathrm{a}}$ & $0.28^{\mathrm{a}}$ & $0.10^{\mathrm{a}}$ & $0.93^{\mathrm{b}}$ & $0.81^{\mathrm{b}}$ \\
& Bidor & $1.19^{\mathrm{b}}$ & $0.11^{\mathrm{b}}$ & $0.13^{\mathrm{a}}$ & $1.61^{\mathrm{a}}$ & $0.70^{\mathrm{b}}$ \\
& Setiu & $0.86^{\mathrm{c}}$ & $0.01^{\mathrm{c}}$ & $0.02^{\mathrm{b}}$ & $0.14^{\mathrm{c}}$ & $1.18^{\mathrm{a}}$ \\
H. odorata & Bukit Hari & $1.61^{\mathrm{a}}$ & $0.43^{\mathrm{a}}$ & $0.09^{\mathrm{b}}$ & $9.90^{\mathrm{a}}$ & $0.51^{\mathrm{a}}$ \\
& Bidor & $1.30^{\mathrm{b}}$ & $0.51^{\mathrm{a}}$ & $0.13^{\mathrm{a}}$ & $1.27^{\mathrm{b}}$ & $0.40^{\mathrm{a}}$ \\
& Setiu & $1.32^{\mathrm{b}}$ & $0.01^{\mathrm{b}}$ & $0.02^{\mathrm{b}}$ & $0.24^{\mathrm{c}}$ & $0.51^{\mathrm{a}}$ \\
& Bukit Hari & $1.31^{\mathrm{a}}$ & $0.28^{\mathrm{b}}$ & $0.10^{\mathrm{a}}$ & $2.63^{\mathrm{a}}$ & $0.93^{\mathrm{a}}$ \\
& Bidor & $1.38^{\mathrm{a}}$ & $0.13^{\mathrm{b}}$ & $0.12^{\mathrm{a}}$ & $1.16^{\mathrm{b}}$ & $0.54^{\mathrm{ab}}$ \\
& Setiu & $0.86^{\mathrm{b}}$ & $1.71^{\mathrm{a}}$ & $0.02^{\mathrm{a}}$ & $0.35^{\mathrm{c}}$ & $0.39^{\mathrm{b}}$ \\
\hline
\end{tabular}

As = Arsenic, $\mathrm{Cd}=$ Cadmium, $\mathrm{Hg}=$ Mercury, $\mathrm{Pb}=$ plumbum and $\mathrm{Cr}=$ chromium; values with the same letter within the same column are not significantly different $(\mathrm{p}<0.05)$ 


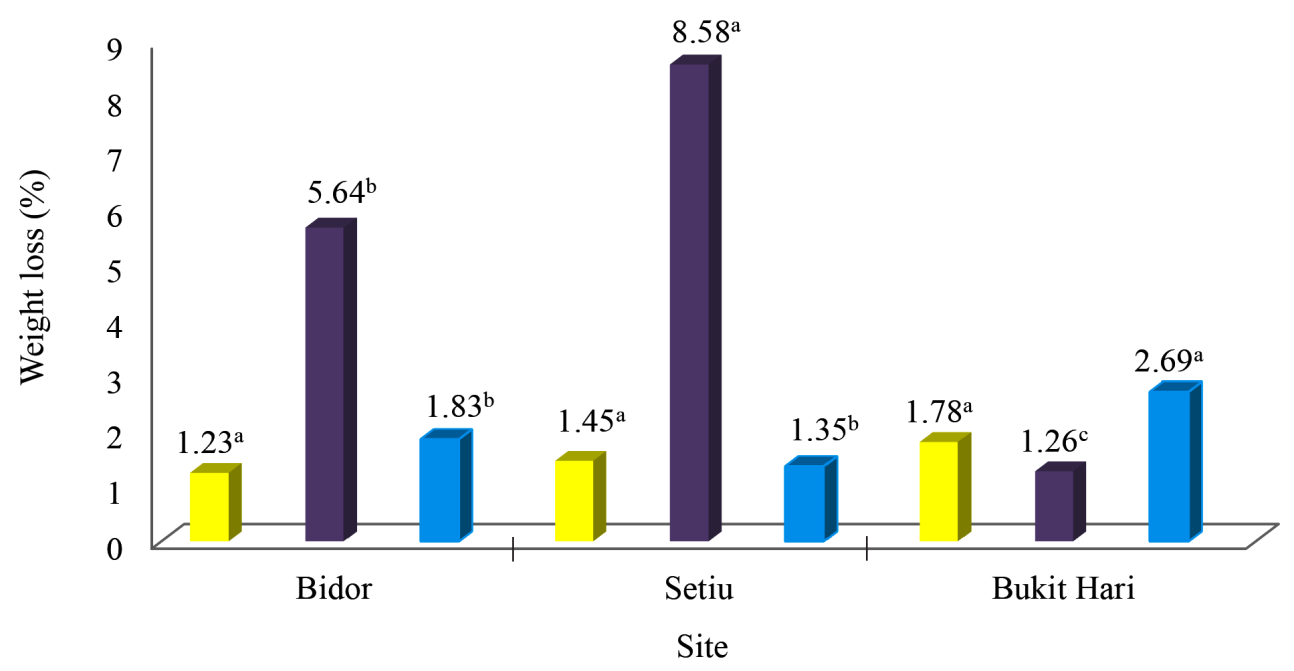

\section{A. mangium $\square$. ivorensis $\square$. odorata}

Figure 2 Average weight loss in laboratory bioassay of three plantation species (Acacia mangium, Hopea odorata and Khaya ivorensis) from three sites against Coptotermes curvignathus; values with the same letter within the same colour are not significantly different $(\mathrm{p}<0.05)$

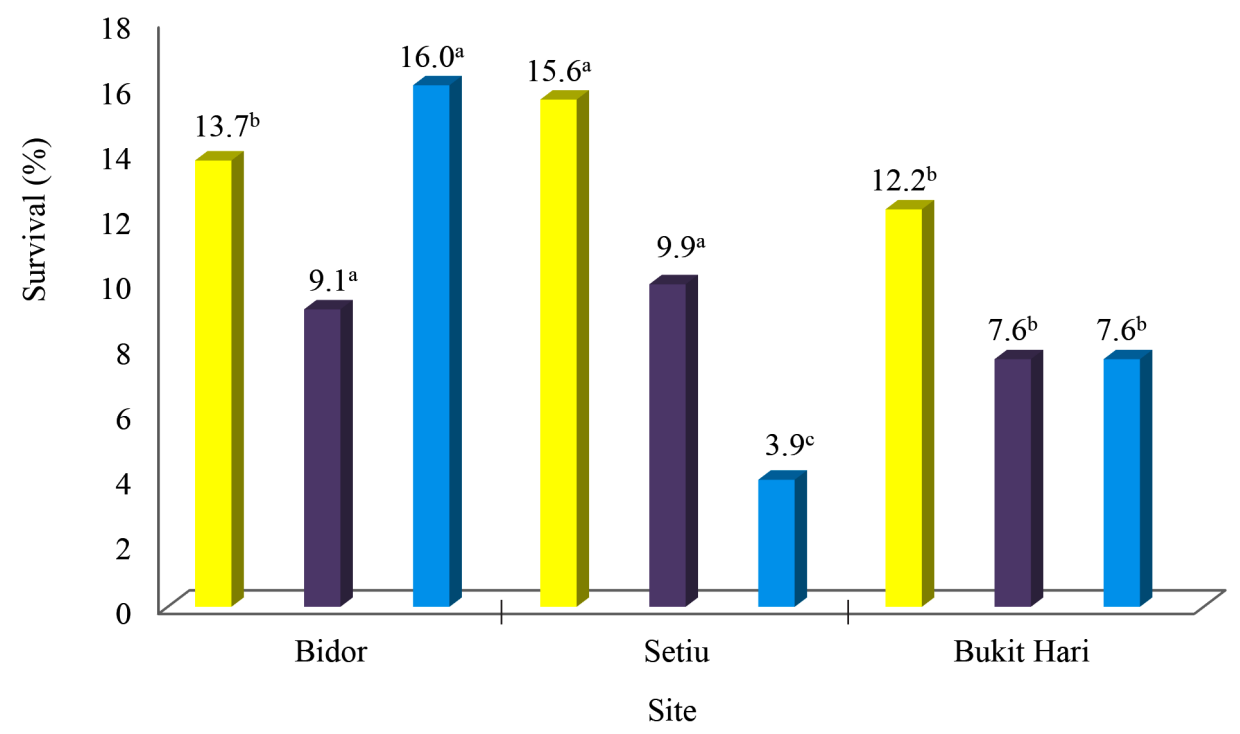

A. mangium $\square$ K. ivorensis $\square$ H. odorata

Figure 3 Average survival of C. curvignathus in laboratory bioassay of three plantation species from three sites; values with the same letter within the same colour are not significantly different $(p<0.05)$

Table 5 Average visual rating in laboratory bioassay of three plantation species from three sites against Coptotermes curvignathus

\begin{tabular}{lccc}
\hline Timber species & \multicolumn{3}{c}{ Site } \\
\cline { 2 - 4 } & Bukit Hari & Bidor & Setiu \\
\hline A. mangium & $9.6^{\mathrm{a}}$ & $8.5^{\mathrm{b}}$ & $9.1^{\mathrm{a}}$ \\
H. odorata & $9.3^{\mathrm{a}}$ & $9.2^{\mathrm{a}}$ & $8.2^{\mathrm{b}}$ \\
K. ivorensis & $9.0^{\mathrm{a}}$ & $9.2^{\mathrm{a}}$ & $9.2^{\mathrm{a}}$ \\
\hline
\end{tabular}

Values with the same letter within the same column are not significantly different $(\mathrm{p}<0.05)$ 
from the other two sites indicated that the Bukit Hari species were more resistant to C. curvignathus (i.e. lesser weight loss) although the values were not significant except for $K$. ivorensis (Figure 2). Khaya ivorensis from Bidor and Setiu was significantly the most susceptible timber species against $C$. curvignathus in the laboratory test. Only $K$. ivorensis showed significantly different weight loss between sites $(\mathrm{F}=62.66519$, $\mathrm{p}<0.05)$.

In general, weight loss in $A$. mangium samples in this study was lower than those grown in normal (i.e. forested area, well-drained, shaded, moist and of high subterranean termite activity) land area (24.9\%) (Grace et al. 1998). This could be due to the heavy metal contents (As and $\mathrm{Pb}$ ) absorbed by this species (Table 3). Acacia mangium has the potential to rehabilitate soil through absorption and storage of heavy metals in its leaves, shoots and roots (Veronica et al. 2011). Besides As, Cd and Pb, other heavy metals present in wood and proven to be detrimental to termites are copper, chromium, cobalt and nickel (Olugbemi 2012). No weight loss against termites is reported for $H$. odorata grown in normal sites such as Bukit Hari, but the species is known to be resistant against subterranean termites (Win \& Aung 2016). Weight loss of K. ivorensis in this study was slightly higher than that reported by Roszaini and Khairul (2018) (3.9-4.4\%). The difference in weight loss for $K$. ivorensis grown in different areas may be due to the absorption of minerals or chemicals (heavy metals) from the soil through the roots. Absorption rates differ according to the wood species due to differences in anatomical and physiological properties of the tree (Doganlar et al. 2012). Different types of soil or soil properties influence the natural durability, extractives content and colour of teak wood (Kokutse et al. 2010).

Survival of C. curvignathus was high in the wood species from the three sites, except for $H$. odorata samples from Setiu (Figure 3). Percentage of weight loss did not always commensurate with survival of termites. Thus, the number of termites that survived at the end of the test should not be the main indicator in determining the durability of the tested wood. Of the three species from all sites, $H$. odorata from Bidor had the highest (16.0\%) survival of C. curvignathus at the end of the four-week experiment.

From the visual ratings, there were significant differences between sites for A. mangium and $K$. ivorensis but not for $H$. odorata (Figure 4).
Results of the visual rating are parallel to wood consumption except for $A$. mangium from Setiu. By all assessment methods, all wood species were particularly resistant to C. curvignathus except for $K$. ivorensis. On the other hand, A. mangium and $H$. odorata planted at Bidor and Setiu sites had lower percentages of wood consumption by termites compared with $K$. ivorensis. This could be due to the higher absorption rates of heavy metals by both timber species (Tagahu et al. 2011).

\section{Aboveground test}

Weight loss and visual rating data of the test blocks exposed to C. curvignathus are presented in Figure 4 and Table 6 respectively. Of 120 replicates for each timber species and site collection, only four samples, i.e. A. mangium from Bukit Hari, $H$. odorata and K. ivorensis from Bidor, and $K$. ivorensis from Setiu sites were attacked. Half of the replicates of $A$. mangium from Bidor and Setiu, and $H$. odorata from Bukit Hari were attacked by termites. A total of six samples of $H$. odorata from Setiu were attacked by C. curvignathus after 16 weeks of exposure. The rest of the species were not attacked. Weight loss of test blocks due to termite attacks was highest for $K$. ivorensis (1.58\% for Bidor, $2.25 \%$ for Setiu and $1.08 \%$ for Bukit Hari) followed by $H$. odorata $(1.11,1.87$ and $0.72 \%$ respectively) and A. mangium (0.31, 0.88 and $0.45 \%$ respectively) (Figure 4 ). ANOVA showed that soil produced very significant difference on weight loss especially for $K$. ivorensis and H. odorata.

From visual rating, it was clear that all timber species from Bidor, except A. mangium, had better performance compared with samples from Setiu and Bukit Hari. There were no significant differences in visual rating between timber species from all sites (except $H$. odorata and $K$. ivorensis from Setiu). The lower weight loss and higher visual rating of $K$. ivorensis samples from Bidor and Setiu in this study than that reported by Roszaini and Khairul (2018), i.e. weight loss $=3.9 \%$ and visual rating $=7$ suggested that the heavy metal content absorbed by the trees planted in the ex-mining and BRIS area can help to improve wood durability against termites. Wood treated with wood preservatives containing heavy metal, e.g. copper chrome arsenic has high resistance against termites and fungi compared with non-heavy metal wood preservatives (e.g. cypermethrin) (Freeman \& McIntyre 2008). 


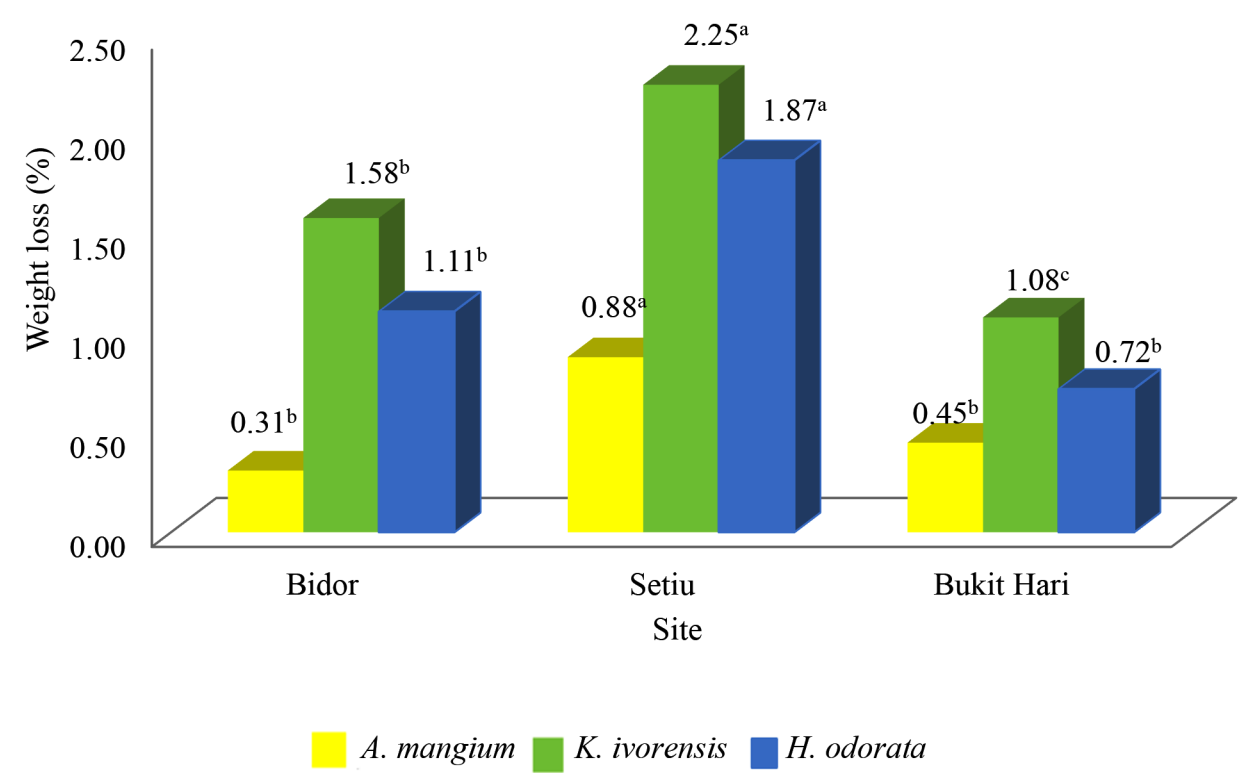

Figure 4 Average weight loss in field test of three plantation species from three sites against C. curvignathus; values with the same letter within the same colour are not significantly different $(\mathrm{p}<0.05)$

Table 6 Average visual rating in field test of three plantation species from three sites against C. curvignathus

\begin{tabular}{lccc}
\hline Timber species & \multicolumn{2}{c}{ Site } \\
\cline { 2 - 4 } & Bukit Hari & Bidor & Setiu \\
\hline A. mangium & $9.9^{\mathrm{a}}$ & $9.5^{\mathrm{b}}$ & $10.0^{\mathrm{a}}$ \\
H. odorata & $9.7^{\mathrm{a}}$ & $9.6^{\mathrm{a}}$ & $8.2^{\mathrm{b}}$ \\
K. ivorensis & $9.8^{\mathrm{a}}$ & $9.2^{\mathrm{a}}$ & $8.0^{\mathrm{b}}$ \\
\hline
\end{tabular}

Values with the same letter within the same column are not significantly different $(\mathrm{p}<$ $0.05)$

\section{CONGLUSIONS}

Timber grown in the ex-mining area had high resistance against subterranean termites due to high heavy metal contents compared with samples from BRIS area. The absorbed heavy metals increased the resistance of all timber species tested especially $A$. mangium and $H$. odorata. However, the contents of the heavy metals were insufficient to make these timber species fully resistant against termites attack.

\section{ACKNOWLEDGEMENTS}

The authors wish to express their sincere gratitude to the staff of the Wood Entomology Laboratory and FRIM sawmill for assisting in sample collection and processing of various timber species. The project was funded under FRIM Board Special Fund (41310404006).

\section{REFERENCES}

Aldoobie NF \& Beltagi MS. 2013. Physiological, biochemical and molecular responses of common bean (Phaseolus vulgaris L.) plants to heavy metals stress. African Journal of Biotechnology 12: 4614-4622.

AWPA (American Wood Protection Association). 2012. Standard test method for evaluation of preservative treatments for lumber and timbers against subterranean termites in above-ground, protected applications (UC1 and UC2). AWPA E21-06. Pp 490494 in AWPA Book of Standards. AWPA, Birmingham.

AWPA. 2017. Laboratory methods for evaluating the termite resistance of wood-based materials: choice and nochoice tests. AWPA E1-17. Pp 416-424 in AWPA Book of Standards. AWPA, Birmingham.

BALL DF. 1964. Loss-on-ignition as an estimate of organic matter and organic carbon in non-calcareous soils. Journal of Soil Science 15: 84-92.

Berg G \& Smalla K. 2009. Plant species and soil type cooperatively shape the structure and function of microbial communities in the rhizosphere. FEMS Microbiology Ecology 68: 1-13. 
Burger JA \& ZipPer CE. 2002. How to Restore Forests on SurfaceMined Land. Virginia Cooperative Extension Service Publication No. 460-123. Virginia Polytechnic and State University, Blacksburg.

Doganlar ZB, Doganlar O, Erdogan S \& Onal Y. 2012. Heavy metal pollution and physiological changes in the leaves of some shrub, palm and tree species in urban areas of Adana, Turkey. Chemical Speciation and Bioavailability 24: 65-78.

EQA (ENvironmental Quality Act). 1974. Laws of Malaysia. Act 127. Percetakan Nasional Malaysia Bhd. Kuala Lumpur.

Freeman \& McIntyre C. 2008. Copper-based wood preservatives a comprehensive review of copper-base wood preservatives. Forest Products Journal 58: 6-27.

Grace JK, Wong AHH \& Tome CHM. 1998. Termite Resistance of Malaysian and Exotic Woods with Plantation Potential: Laboratory Evaluation. IRG/WP Document 9810280. International Research Group on Wood Preservation, Stockholm.

Hashim MN, Mohd Hazim MA \& Syafinie AM. 2015. Strategic forest plantation establishment in Malaysia for future product development and utilization. International Journal of Agriculture, Forestry and Plantation 1: 14-24.

Jeyanny V, Ahmad Zuhaidi Y, Fakhri MI \& Syaliny G. 2017. Phytoremediation of heavy metals using Acacia mangium in Rahman Hydraulic Tin (RHT) tailings. Pp 38-43 in Ho WM et al. (eds) Proceedings Seminar on Reclamation, Rehabilitation and Restoration of Disturbed Sites: Planting of National and IUCN Red List Species. 15-17 August 2017, Kuala Lumpur.

Kirton LG, Brown VK \& Azmi M. 1998. A new method of trapping subterranean termites of the genus Coptotermes (Isoptera: Rhinotermitidae) for field and laboratory studies. Sociobiology 32: 451-458.

Kokutse AD, Amusant N, Boutahar N \& Chaix G. 2010. Influence of soil properties on the natural durability, extractive content and colour of teak (Tectona grandis L.f.) wood in Togo. Annales de l'Université de Parakou. Série Sciences Naturelles et Agronomie 1: 37-50.

LAURILA R. 1995. Wood properties and utilization potential of eight fast-growing tropical plantation tree species. Journal of Tropical Forest Products 1: 209-221.

LOK EH \& ONG TH. 2002. Khaya ivorensis. Pp 215-229 in Krisnapillay B (ed). A Manual for Forest Plantation Establishment in Malaysia. Malayan Forest Records No. 45. Forest Research Institute Malaysia, Kepong.

Mohd Khairi CL, Mohd Nozulaidi N, Musliania MI \& Khanif MSJ. 2011. Composting increases
BRIS soil health and sustains rice production. ScienceAsia 37: 291-295. https://doi: 10.2306/ scienceasia1513-1874.2011.37.291.

Ncube E \& Phiri B. 2015. Concentrations of heavy metal in Eucalyptus and Pinus wood sawdust and smoke, Copperbelt province, Zambia. Maderas Ciencia y Technologia 17: 585-596.

Nossin JJ. 1964. Beach ridges of the east coast of Malaya. Tropical Geography Journal 18: 111-117.

Nwajei GE \& Iwegbue CMA. 2007. Trace elements in sawdust particles in the vicinity of sawmill in Sapele, Nigeria. Pakistan Journal of Biological Siences 10: 4311-4314.

Olugbemi B. 2012. Termiticidal activity of Parkia biglobosa (Jacq.) Benth. seed extracts on the termite Coptotermes intermedius Silvestri (Isoptera: Rhinotermitidae). Psyche 2012: 1-5. https://doi. org $/ 10.1155 / 2012 / 869415$.

Roszaini K \& Khairul M. 2018. Heartwood durability of Dyera costulata, Neolamarckia cadamba and Khaya ivorensis trees from fast-growth plantation against subterranean termite Coptotermes curvignathus. Holzforschung 72: 143-149.

Smith RT \& Atkinson K. 1975. Techniques in Pedology. A Handbook for Environmental and Resource Studies. Paul Elek (Scientific Books) Ltd., London.

Tagahu V, Siti Rozaimah SA, Hassan B, Mushrifah I, Nurina A \& Muhammad M. 2011. Review on heavy metals (As, $\mathrm{Pb}$, and $\mathrm{Hg}$ ) uptake by plants through phytoremediation. International Journal of Chemical Engineering 2011: 1-31.

Thompson M \& Wood SJ. 1982. Chapter 4g: Atomic absorption methods in applied geochemistry. Techniques and Instrumentation in Analytical Chemistry 5: 261-284.

Veronica J, Majid NM, Islam MM \& Arifin A. 2011. Assessment of heavy metal uptake and translocation in Acacia mangium for phytoremediation of cadmium contaminated soil. Journal of Food Agriculture and Environment 9: 588-592.

Wan Asma I, Wan Rasidah K, Rosenani AB, Aminuddin H \& Rozita A. 2011. Effects of mulching and fertiliser on nutrient dynamics of sand tailings grown with Acacia hybrid seedlings. Journal of Tropical Forest Science 23: 440-452.

Win CC \& Aung LL. 2016. Investigation on the decay and termite resistance of five wood species from Tanintharyi region. Leaflet No. 15/2016. Ministry of Natural Resources and Environmental Conservation Forest Department, Naypyidaw. 